\title{
TROPHIC STATE OF SMALL RETENTION RESERVOIRS IN PODLASIE VOIVODESHIP
}

\author{
Joanna Szczykowska ${ }^{1 *}$, Anna Siemieniuk ${ }^{1}$, Józefa Wiater ${ }^{1}$ \\ 1 Bialystok University of Technology, Department of Technology in Engineering and Environmental Protection, \\ Wiejska St. 45E, 15-351 Białystok, Poland \\ * Corresponding author's e-mail: j.szczykowska@pb.edu.pl
}

Received: 2017.05.11

Accepted: 2017.08.01 Published: 2017.09.01

\begin{abstract}
The study was carried out using water samples from two small retention reservoirs located in the communes: Czarna Białostocka and Turośn Kościelna in Podlaskie Voivodeship. The main tasks of both reservoirs are to improve the water balance by means of regulating the levels and water outflow. Three characteristic measurement and control points were selected on both reservoirs in accordance to the water flow in the longitudinal section. The first and third points were located near the inflow and outflow of water, while the second in the middle of the reservoirs. Samples of water for the study were collected from the surface layer of the shore zone of the reservoirs once a month from March 2015 to February 2017 (water from two hydrological years was analyzed). Water samples were subject to determination of total phosphorus, total nitrogen, and chlorophyll "a" concentrations, as well as turbidity. Contamination of the water reservoirs with biogenic compounds is a common problem and at the same time difficult to eliminate due to the scattered nature of external sources of pollution, especially in the case of agricultural catchments, as well as the inflow of untreated sewage from areas directly adjacent to the reservoirs. Based on achieved results, high values of TSI (TN), TSI (TP), TSI (Chl), and overall TSI, clearly indicate the progressive degradation of water quality in analyzed reservoirs. Appearing water blooms due to the mass development of phytoplankton adversely affect the quality of water in the reservoirs and biochemical processes occurring both in water and bottom sediments, are conditioned by progressive eutrophication.
\end{abstract}

Keywords: eutrophication, trphic state index, retention reservoir

\section{INTRODUCTION}

Eutrophication of water can occur spontaneously, without human intervention, developing for many years. In contrast, in the case of anthropogenic eutrophication, the effects of this process can be seen and felt only after a few or several years. In addition to nutrients of natural or anthropogenic origin, the process is supported by some microelements, light, vitamins, and temperature, as well as hydrobiological, hydrodynamic, and morphological properties of surface water bodies [Kowalewski 2012]. Construction of retention reservoirs, regardless of their capacity, is closely related to increased water resources. Most of them, built in recent years, are characterized by a small depth and surface, and relatively quick water exchange process leading to the lack of or intensive depletion of thermal water stratification. Many factors are responsible for the quality of shallow barrier water reservoirs and the process of shaping their physicochemical properties takes place in various aspects. The trophic level of the reservoir water is the result of its morphological characteristics, quality of the inflowing water, and natural and anthropogenic conditions of a catchment [Bogdał et al., 2015]. The most important negative effects of eutrophication are first of all the loss of tourist, recreational, and landscape values of small retention reservoirs and even a 
threat to human and animal health. Although one of the most noticeable effects is elevated turbidity and water color, the greatest danger is caused by toxins secreted by rapidly evolving cyanobacteria in the eutrophic environment and present in the so-called water blooms [Namikoshi et al., 2003]. The effect of cyanobacterial blooms is a high concentration of biomass (from several dozen to several hundred milligrams of fresh weight $\left./ \mathrm{dm}^{3}\right)$, loss of species biodiversity, reduction in biocenotic system stability, presence of large numbers of bacteria, especially during the stage of cyanobacterial decay, photosynthesis inhibition in planktonic algae accompanying the cyanobacteria, and deep oxygen deficits in the water depth [Burhardt, Pawlik-Skowrońska, 2015]. The main causes of deepening the negative effects of the anthropogenic eutrophication process are discharges of impurities from the municipal and industrial sectors, as well as biogenic compounds from mineral and organic fertilizers that are commonly used in agriculture. Therefore, an essential element of a proper functioning and management of water resources in barrier reservoirs is the monitoring (control) of inflowing biogenic compounds, mainly nitrogen and phosphorus. Analysis of the trophic status of surface water ecosystems is an important issue for many research projects. Priority in this regard is to obtain versatile indicators for the most accurate determination of trophic status of water and to further assess their vulnerability to eutrophication, taking into account the directions of change. Basic indicators commonly applied to evaluate the trophic status of water are trophy status indices (TSIs) calculated based on the concentrations of chlorophyll "a", total phosphorus, total nitrogen, as well as visibility of Secchi disc, turbidity, and aerobic conditions [Szczykowska et al., 2015]. Determining the TSI value only by measuring the visibility of the Secchi disc and the total nitrogen and total phosphorus concentrations does not accurately characterize the trophic status of water. Visibility of the Secchi disc is limited as a trophic index especially for shallow reservoirs, where not only the particles of algae floating in the water cause the turbidity [Carlson, 2007, Szczykowska et al., 2015]. The turbidity degree depends primarily on the concentration of insoluble organic and inorganic compounds, including fine soil particles, rock particles, iron and manganese compounds, humic substances, plant and animal debris.

Therefore, the concentration of chlorophyll "a" may be a more accurate indicator [Carlson, 2007]. Chlorophyll "a" as a pigment found in chloroplasts of plant cells is involved in photosynthesis of algae and bacteria [Bao-Zhu Pan et al., 2009], hence, its concentration is used as a parameter to take into account the amount of phytoplankton when assessing the trophic status of surface water.

The aim of the study was to determine the value of trophic indicators of water in two small retention reservoirs threatened by eutrophication.

\section{RESEARCH AREA AND METHODOLOGY}

The study was carried out using water samples from two small retention reservoirs located in the communes: Czarna Białostocka and Turośń Kościelna in Podlaskie voivodeship. The main tasks of both reservoirs are to improve the water balance by means of regulating the levels and water outflow. Selection of research facilities was made due to the similarity of the management type of inflowing watercourse catchment, methods of using the retention water, and small area of both reservoirs, the basic technical data of which are given in Table 1.

Czapielówka small retention Reservoir is located on the Jurczycha river and divides the watercourse into two sections with separate elementary catchments assigned to them. The first section of the river from its source to the reservoir Czapielówka of $3.72 \mathrm{~km}$ length, creates a catchment

Table 1 Basic parameters of small retention reservoirs

\begin{tabular}{|l|c|c|c|}
\hline \multicolumn{1}{|c|}{ Basic parameters } & Units & Czarna Białostocka & Turośń Kościelna \\
\hline River & - & Jurczycha & Turośnianka \\
\hline Normal level of damming & $\mathrm{m}$ a.s.l. & 147 & 124.5 \\
\hline Reservirs surface & $\mathrm{ha}$ & 316955 & 8.2 \\
\hline Retention capacity of reservoir & $\mathrm{m}^{3}$ & 2 & 94500 \\
\hline Average depth of the reservoir & $\mathrm{m}$ & 16.5 & 1.5 \\
\hline Surface of catchment basin & $\mathrm{km}^{2}$ & & 19.5 \\
\hline
\end{tabular}


area of $12.15 \mathrm{~km}^{2}$ and circumference of $17.6 \mathrm{~km}$. The other section is a fragment of the river from the reservoir Czapielówka to its estuary, with the length of $5.77 \mathrm{~km}$, catchment area of $22.75 \mathrm{~km}^{2}$ and circumference of $25.52 \mathrm{~km}$ [KZGW, $2010 \mathrm{~b}$ ]. The artificial Reservoir Czapielówka created in the 1970s between them, belongs to the so-called small retention barrier reservoirs, the main task of which is to improve the water balance by regulating the levels and water outflow. This effect was achieved by damming the Jurczycha river with a dam on the $7 \mathrm{~km}$. Generally, river catchment area management can be considered in the forestry and agricultural category. The catchment area of Czapielówka Reservoir is located in the middle of spruce and pine forests, and the springs - among meadows used for agricultural purposes. The area is covered by rusty soils mostly developed from sands (loose and weak loams), which are acidic and permeable. A small proportion of soils, there are podzolic and lessive ones. Most of the arable land is located on weak soils of V and VI class and in a small amount - class IV, that are of average quality. In the immediate vicinity of the river bed, there are grasslands located on peat, peatmarsh, and chernozem soils.

The other reservoir is located in the central part of the residential estate in Turośn Kościelna and was created in the depression of the Turośnianka river valley, that divides the catchment in asymmetric way, which means that it flows closer to the southern border of the watershed. The length of the river from its source in Kudrycze to the section that closes the reservoir is $21.5 \mathrm{~km}$. The river and its valleys are natural with existing bends, meanders, and changes in direction. The elevations around the reservoir, on which the buildings are located, reach $136.7 \mathrm{~m}$ in the south and $132.00 \mathrm{~m}$ in the northern part. The river valley itself is located at a relative elevation of 123-124 m. The transverse sections of the embankments show that the southern edge is marked more clearly and the northern margin is a plane with a gentle slope and with a deep-cut channel, which is about $2-2.5 \mathrm{~m}$ of height. In the immediate vicinity of the reservoir, there are housing estates that are characterized by dense building development and accompanying farm buildings. The catchment area is used by agriculture, but part of it is a wasteland. The land in the catchment area situated in the direct vicinity of the reservoir is classified as IV and V bonitation class of soil, which in $69.9 \%$ is used as grassland, while arable land constitutes $1.2 \%$, and the share of wasteland is $18.1 \%$. Areas adjacent to the riverbed are muck and peat soils.

Three characteristic measurement and control points were selected on both reservoirs in accordance to the water flow in the longitudinal section. The first and third points were located near the inflow and outflow of water, while the second in the middle of the reservoirs. Samples of water for the study were collected from the surface layer of the shore zone of the reservoirs once a month from March 2015 to February 2017 (water from two hydrological years was analyzed). Water samples were subject to determination of total phosphorus, total nitrogen, and chlorophyll "a" concentrations, as well as turbidity. The transparency determined as the visibility on Secchi disc was given up in the study as it is of secondary importance in assessing trophic status in shallow barrier reservoirs. Water inflowing during heavy rainfall introduces large quantities of sediments that cause turbidity of retained water. However, reduction in transparency caused by this fact is not related to the development of phytoplankton [Szczykowska 2015].

The assessment of the water bodies eutrophication degree is carried out using the average annual concentrations of biogenic compounds and chlorophyll "a". The total phosphorus concentration was determined with pre-mineralization in sulfuric acid, according to the HACH method using a DR 4000 spectrophotometer. Total nitrogen was determined by the Kjeldahl method, which consists of mineralization of nitrogenous organic compounds in concentrated sulfuric acid (VI) with perhydrol at high temperature according to HACH methodology. Chlorophyll "a" tests were performed using the extraction-spectrophotometric method in accordance with PN86-C-05560/02. For the purposes of this study, the results were grouped according to the seasons: spring (from March to May), summer (from June to August), autumn (from September to December) and winter (from December to February), as well as minimum, maximum and average values were calculated. Trophic status of reservoirs was assessed on the basis of the trophic indices of TSI (Chl) in $\mu \mathrm{g} / \mathrm{dm}^{3}$ and TSI (TP) in $\mu \mathrm{g} / \mathrm{dm}^{3}$ according to Carlson and TSI (TN) in $\mathrm{mg} / \mathrm{dm}^{3}$ according to Kartzer and Brezonik (Figures 1-4), as well as TSI level using the average values obtained from the three calculated TSI (Chl), TSI (TP) TSI (TN), was evaluated. 


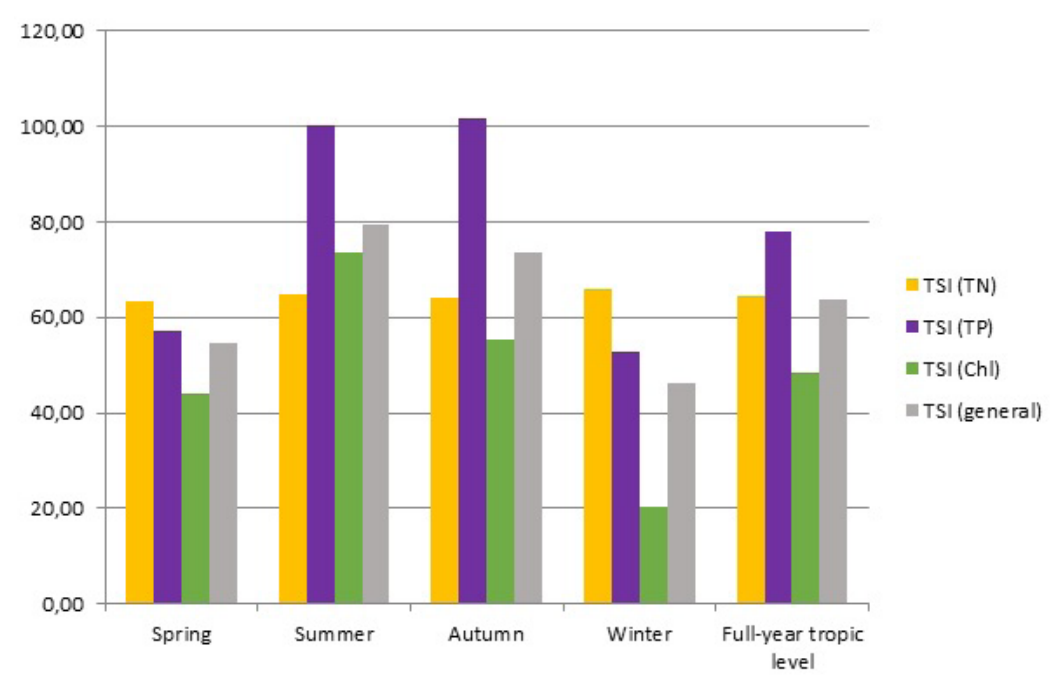

Fig. 1 Trophic state index in Czapielówka reservoir in 2015-16

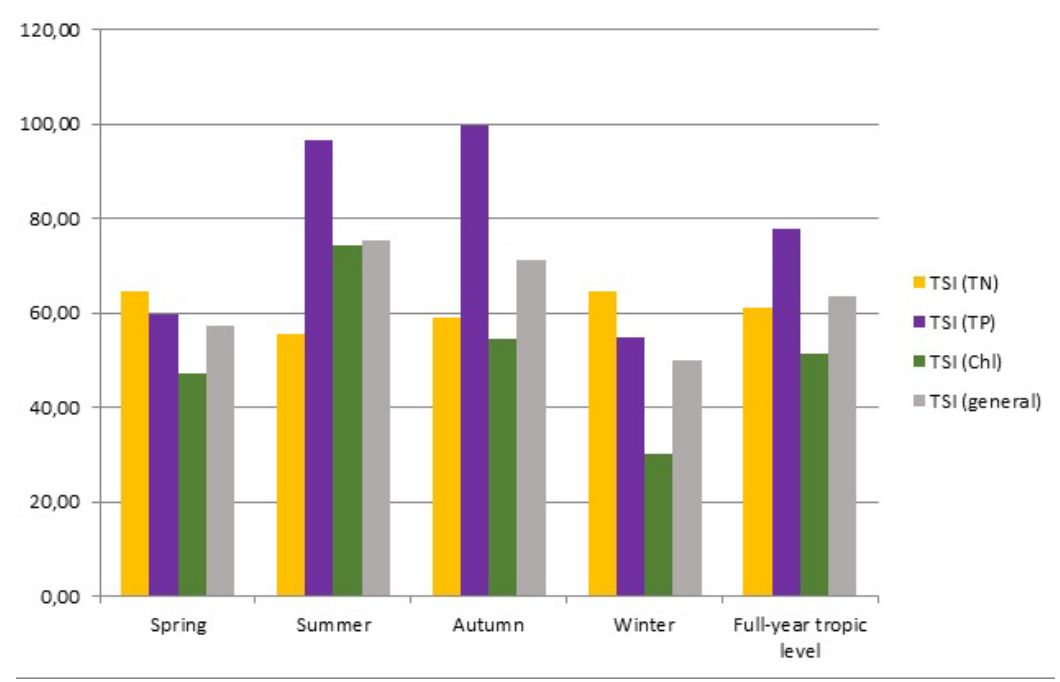

Fig. 2 Trophic state index in Czapielówka reservoir in 2016-17

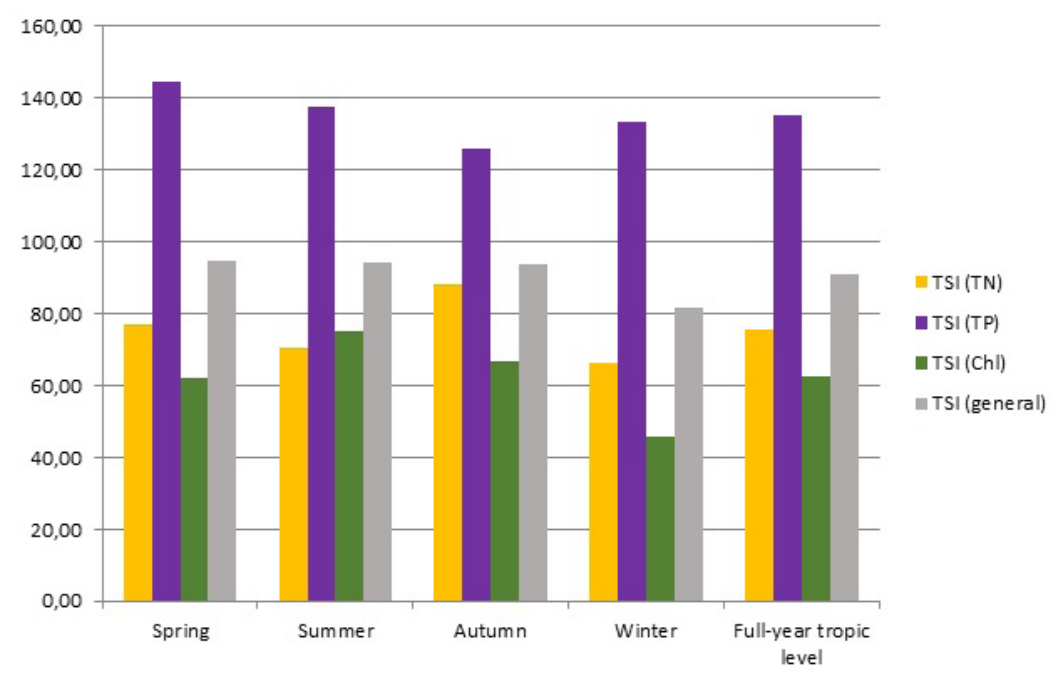

Fig. 3 Trophic state index in Turośń Kościelna reservoir in 2015-16 


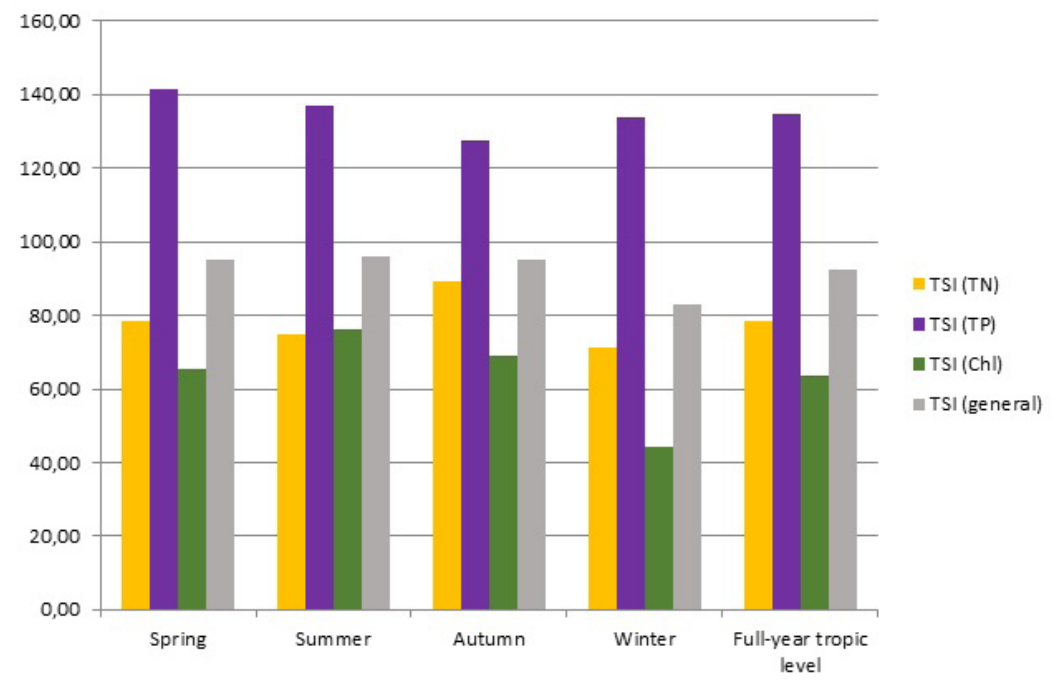

Fig. 4 Trophic state index in Turośń Kościelna reservoir in 2016-17

\section{RESULTS AND DISCUSSION}

Results of total phosphorus, total nitrogen, chlorophyll "a", and turbidity concentrations in water samples from small retention reservoirs Czapielówka and Turośń Kościelna are presented in Tables 2 and 3.

The average concentration of total phosphorus in water from Czapielówka reservoir during the study period was $0.598 \mathrm{mg} \mathrm{P} / \mathrm{dm}^{3}$ and in the subsequent season $2016-17$, it was only slightly lower and amounted to $0.561 \mathrm{mg} \mathrm{P} / \mathrm{dm}^{3}$. Concentration of phosphorus in the water of examined reservoir varied depending on the seasons and the lowest one was determined in winter and spring, whereas during summer and autumn, it was more than twenty times higher at all measurement and control points as compared to autumn, when they ranged from $0.3042 \mathrm{mg} \mathrm{P} / \mathrm{dm}^{3}$ to $1.681 \mathrm{mg} \mathrm{P} / \mathrm{dm}^{3}$ (Table 1).

Water from Turośń Koscielna Reservoir revealed significantly higher average annual total $\mathrm{P}$ concentration, which in the first year of research was $9.06 \mathrm{mg} \mathrm{P} / \mathrm{dm}^{3}$, and in the second year, it was almost by $1 \mathrm{mg} \mathrm{P} / \mathrm{dm}^{3}$ higher. The concentration of phosphorus in the water of this reservoir far exceeded the limit of eutrophication. Particularly high concentrations of this biogen occurred in

Table 2 Research results of Czapielówka reservoir

\begin{tabular}{|c|c|c|c|c|c|c|}
\hline \multicolumn{7}{|c|}{ Years 2015-16 } \\
\hline Parameter & Units & $\frac{\text { Min-max }}{\text { average }}$ & Spring & Summer & Autumn & Winter \\
\hline Total phosphorus & $\mathrm{Mg} \mathrm{P} / \mathrm{dm}^{3}$ & $\frac{0.036-1.681}{0.598}$ & 0.0397 & 0.792 & 0.873 & 0.029 \\
\hline Total nitrogen & $\mathrm{mg} \mathrm{N} / \mathrm{dm}^{3}$ & $\frac{0.33-3.08}{1.626}$ & 1.833 & 2.041 & 1.954 & 2.233 \\
\hline Chlorophyll „a” & $\mu \mathrm{g} / \mathrm{dm}^{3}$ & $\frac{0.24-87.3}{24.54}$ & 3.87 & 79.2 & 12.35 & 0.35 \\
\hline Turbidity & NTU & $\frac{1.3-11.8}{4.57}$ & 1.96 & 4.28 & 6.25 & 1.18 \\
\hline \multicolumn{7}{|c|}{ Years 2016-17 } \\
\hline Parameter & Units & $\frac{\text { Min-max }}{\text { average }}$ & Spring & Summer & Autumn & Winter \\
\hline Total phosphorus & $\mathrm{mg} \mathrm{P} / \mathrm{dm}^{3}$ & $\frac{0.021-1.273}{0.561}$ & 0.047 & 0.607 & 0.752 & 0.034 \\
\hline Total nitrogen & $\mathrm{mg} \mathrm{N} / \mathrm{dm}^{3}$ & $\frac{0.41-3.56}{1.896}$ & 2.009 & 1.089 & 1.385 & 2.022 \\
\hline Chlorophyll „a” & $\mu \mathrm{g} / \mathrm{dm}^{3}$ & $\frac{0.35-92.8}{30.12}$ & 5.43 & 86.9 & 11.42 & 0.95 \\
\hline Turbidity & NTU & $\frac{0.72-9.1}{3.37}$ & 2.49 & 4.42 & 5.52 & 1.04 \\
\hline
\end{tabular}


Table 3 Research results of reservoir in Turośń Kościelna

\begin{tabular}{|c|c|c|c|c|c|c|}
\hline \multicolumn{7}{|c|}{ Years 2015-16 } \\
\hline Parameter & Units & $\frac{\text { Min-max }}{\text { average }}$ & Spring & Summer & Autumn & Winter \\
\hline Total phosphorus & $\mathrm{mg} \mathrm{P} / \mathrm{dm}^{3}$ & $\frac{3.92-21.34}{9.06}$ & 16.93 & 10.30 & 4.67 & 7.68 \\
\hline Total nitrogen & $\mathrm{mg} \mathrm{N} / \mathrm{dm}^{3}$ & $\frac{2.13-12.58}{4.80}$ & 4.75 & 3.03 & 10.3 & 2.3 \\
\hline Chlorophyll „a” & $\mu \mathrm{g} / \mathrm{dm}^{3}$ & $\frac{2.04-105.0}{41.28}$ & 25.15 & 95.0 & 40.23 & 4.81 \\
\hline Turbidity & NTU & $\frac{2-19}{9.25}$ & 12.6 & 8.0 & 10.2 & 6.2 \\
\hline \multicolumn{7}{|c|}{ Years 2016-17 } \\
\hline Parameter & Units & $\frac{\text { Min-max }}{\text { average }}$ & Spring & Summer & Autumn & Winter \\
\hline Total phosphorus & $\mathrm{mg} \mathrm{P} / \mathrm{dm}^{3}$ & $\frac{4.16-23.66}{10.014}$ & 13.87 & 9.87 & 5.12 & 8.04 \\
\hline Total nitrogen & $\mathrm{mg} \mathrm{N} / \mathrm{dm}^{3}$ & $\frac{3.12-13.27}{5.984}$ & 5.31 & 4.15 & 11.07 & 3.24 \\
\hline Chlorophyll „a” & $\mu \mathrm{g} / \mathrm{dm}^{3}$ & $\frac{1.93-107.3}{49.321}$ & 35.26 & 104.2 & 51.19 & 3.97 \\
\hline Turbidity & NTU & $\frac{3-21}{10.15}$ & 11.9 & 9.2 & 11.0 & 5.9 \\
\hline
\end{tabular}

spring in both studied years amounting respectively to $13.21 \mathrm{mg} / \mathrm{dm}^{3}$ and $21.34 \mathrm{mg} / \mathrm{dm}^{3}$.

At the turn of February and March, during the spring floods associated with thawing and precipitation, there was a significant increase in the concentration of phosphorus compounds in the water entering the Turośn reservoir as compared to the average values in the remaining quarters. A sharp increase in total phosphorus over that period may indicate the origin of phosphorus compounds from both external and internal sources. The internal source was decayed biomass transferred to bottom sediments in earlier periods, which, after melting the ice cover through spring circulation, penetrated into the water depth by means of resuspension of sediments. Untreated wastewater from the non-canalized areas in the immediate vicinity of the reservoir was the most important source of phosphorus accumulation in the aquatic environment of this reservoir, making an external source of significant amounts of phosphorus.

The results are confirmed by previous studies performed by Sapek (2014) and Szczykowska (2014), who argue that migration of phosphorus through the surface runoff requires particular attention, because this runoff is an important way of transporting phosphorus to the surface water. After this period, the intensity of the water flow in rivers slowed down, which probably also influenced the dynamics of bottom sediments and less phosphorus release. Water samples collected in autumn months were characterized by the lowest concentrations of $\mathrm{P}$ ranging from $3.92 \mathrm{mg} \mathrm{P} / \mathrm{dm}^{3}$ to $23.66 \mathrm{mg} \mathrm{P} / \mathrm{dm}^{3}$. This was due to the poorly mixed process of water in the reservoir as compared to the spring.

Besides phosphorus, nitrogen is the biogen that determines the eutrophication of surface water. The mean annual concentrations of total $\mathrm{N}$ in the water of Czapielówka reservoir in the first study period was $1.626 \mathrm{mg} \mathrm{N} / \mathrm{dm}^{3}$ and in the second one, it was by $0.27 \mathrm{mg}$ higher. By analyzing the results of total nitrogen determination in the reservoir Czapielówka, it can be stated that the highest concentration was determined during winter, which was the result of changes in organic matter and limitation of biological life in the socalled dead time. In remaining seasons of the year, concentration of this biogen in water of this reservoir was slightly lower and close to each other. It can be seen that during the growing season, a slight decrease in $\mathrm{N}$ concentration was observed, which was influenced by autotrophic aquatic organisms and plants developing during that period. In conclusion, it can be stated that there are favorable conditions for algae growth in the reservoir.

The total nitrogen concentration in water of the Turośn Kościelna reservoir varied from 2.13 to $13.27 \mathrm{mg} \mathrm{N} / \mathrm{dm}^{3}$, but no significant seasonal occurrence or water self-cleaning was observed. The average annual $\mathrm{N}$ concentration in the period from March 2015 to February 2016 was 4.8 $\mathrm{mg} \mathrm{N} / \mathrm{dm}^{3}$ and in the corresponding period of 2016-17, it was higher by more than $1 \mathrm{mg} \mathrm{N} / \mathrm{dm}^{3}$. The reason for high concentrations of nitrogen during most of the study period was the leakage 
of untreated municipal-farm sewage from the surrounding inhabited residential areas into the reservoir waters, which was reduced in winter due to the frosted ground. The relatively high values of the analyzed parameter at all measurement points in autumn indicate that conditions favored the biodegradation of organic matter. Decomposition of organic compounds in the aquatic environment can take place with the aid of microorganisms, both in aerobic and anaerobic conditions, which is referred to as biodegradation, which results not only in the modification of functional groups. In the majority of cases, the basic structure of the compound eventually decays to a complete decomposition into carbon dioxide, water and inorganic salts [Jeannot, 1994, Kot-Wasiak 2001].

Trophic level of the water reservoir is an important factor in its functioning and in its comprehensive use for planned purposes. The content of chlorophyll "a" is a relatively simple indicator for evaluation, unfortunately with some disadvantages. Errors can arise from the fact that pigment concentrations may vary depending on the physiological characteristics of algae cells or their species affiliation. Algae cells, under worse light conditions, contain more chlorophyll than those exposed to more intensive irradiation [Kasprzak et al. 2008, Neverowa-Dziopak, 2010]. In shallow reservoirs, the abundant growth of algae or cyanobacteria during blooms occurs throughout the entire water volume and greatly degrades the water quality. Excessive water blooms prevent recreational use of the reservoir. Chlorophyll "a" concentrations fluctuated in waters of Czapielówka reservoir in the range of $0.24-92.8 \mu \mathrm{g} / \mathrm{dm}^{3}$, while in waters of Turośń Kościelna reservoir in the range of $1.93-107.3 \mu \mathrm{g} / \mathrm{dm}^{3}$. In the water of both reservoirs, seasonal oscillations in chlorophyll "a" concentrations were recorded. The winter period was characterized by the lowest concentrations of chlorophyll, which in Czapielówka reservoir was within the range of $0.24-1.04 \mu \mathrm{g} / \mathrm{dm}^{3}$ and in Turośń Kościelna 1.93-5.15 $\mu \mathrm{g} / \mathrm{dm}^{3}$. At the beginning of the growing season, chlorophyll concentrations gradually increased and the highest values of $85.7-92.8 \mu \mathrm{g} / \mathrm{dm}^{3}$ in Czapielówka and $90.7-105.0 \mu \mathrm{g} / \mathrm{dm}^{3}$ in Turośń Kościelna, were determined in summer due to favorable conditions for the photosynthesis process. Inflow of nutrients from agricultural catchment and householdfarm wastewater along with slowing water flow in water reservoirs as compared to inflow streams, favor the eutrophication processes, while simultaneously providing a barrier to good ecological status of these reservoirs. The response to the in- creasing fertility of the reservoirs is the increase in spring and summer maxima of chlorophyll "a" concentrations. Values of the total trophic status (Trophic State Index) calculated based on the studies carried out in 2015-16 in Czapielówka reservoir ranged from 46.35 in winter to 79.54 in summer, whereas in 2016-17 from 49.9 in winter to 75.55 in summer, which indicates a variable trophic status from mesotrophic to hypertrophic (Figures 1 and 2). Comparing the obtained results with ranges characteristic for particular trophy states according to Carlson's [Carlson, 2007], it can be concluded that the Czapielówka reservoir, in terms of total phosphorus concentration, is hypertrophic, in terms of total nitrogen concentration - eutrophic, whereas due to the concentration of chlorophyll "a", it is classified as a mesotrophic reservoir (Figures 1 and 2). Throughout the study period, the overall trophy level for the Turośń reservoir was characterized by values for the TSI (TP) from 125.98 in autumn to 144.56 in spring, while for the TSI (CHL), it was from 44.13 in winter to 76.18 in summer. Differences between minimum and maximum trophic index values were achieved for TSI (TP), while for TSI (CHL) - 33. Comparing the achieved results with Carlson's specific trophic states, it can be stated that the trophy assessed for Turośń Kościena reservoir is hypertrophic in relation to the concentration of phosphorus, whereas the concentration of chlorophyll "a" qualifies it as a eutrophic to hypertrophic reservoir. In contrast, the TSI (TN) values ranged from 66.47 in winter to 89.14 in autumn, classifying water in the reservoir as mesotrophic to hypertrophic.

Contamination of the water reservoirs with biogenic compounds is a common problem and at the same time difficult to eliminate due to the scattered nature of external sources of pollution, especially in the case of agricultural catchments, as well as the inflow of untreated sewage from areas directly adjacent to the reservoirs. Watercourse entering the reservoir brings biogenic substances with water, which directly affects the water quality, causing their high concentrations, or indirectly involving the initiation or acceleration of reservoir eutrophication and the loss of its usefulness. Based on achieved results, high values of TSI (TN), TSI (TP), TSI (Chl), and overall TSI, clearly indicate the progressive degradation of water quality in analyzed reservoirs. Appearing water blooms due to the mass development of phytoplankton adversely affect the quality of water in the reservoirs and biochemical processes occurring both in water and bottom sediments, are conditioned by progressive eutrophication. 


\section{CONCLUSIONS}

1. Supply of nutrients from the agricultural catchment and household-farm wastewater, together with slowing the water flow in the reservoirs as compared to the supplying watercourses, favors the eutrophication processes, while also posing a barrier to good ecological status of the reservoir waters.

2. During the study period, value of the annual overall trophy level expressed as TSI (general) was 63 , which enabled the water in the reservoir Czapielówka to classify as eutrophic, whereas in the case of reservoir in Turośń Kościelna, the calculated value of this indicator was over 90, which indicates its hypertrophic character.

3. Described seasonal changes in P content indicate the release of phosphorus from bottom sediments and secondary pollution of reservoir waters.

4. Phosphorus and nitrogen compounds supplied from external sources have been shown indicators that univocally adversely affected the trophy status of water in both reservoirs.

\section{REFERENCES}

1. Artebjerg G.: Eutrophication in Europe's coastal waters, EEA Trophic Report 7/2001.

2. Bao-Zhu Pan, Hai-JunWang, Xiao-Min Liang, HongZhu Wang, 2009, Factors influencing Chlorophyll a concentration in the Yangtze-connected lakes, Fresenius Environmental Bulletin, 18(10), 1894-1900.

3. Bednarz T., Mazurkiewicz-Boroń G., 2002, Microbiological processes associated with algae and cyanobacterial blooms, Botanical News, 46(1/2), 45-55. [in Polish]

4. Bogdał A., Kowalik T., Witoszek K., 2015, Impact of Goczałkowicki reservoir on changes in water quality in the Vistula river, Environmental Engineering, 45, 124-134. [in Polish]

5. Bogdanowicz R., 2004, Hydrological determinants of transport of selected nitrogen and phosphorus compounds of Odra and Vistula and rivers of Przymorze to the Baltic, Wydawnictwo Uniwersytetu Gdańskiego, Gdańsk. [in Polish]

6. Burhardt L., Pawlik-Skowrońska B., 2015 The cyanosis bloat - Interspecific competition and environmental threat, Botanical News, 49(1/2), 39-49. [in Polish]

7. Carlson R.E., 2007, EstimatingTrophicState, Lakeline/Spring, pp. 25-28

8. Czaplicka-Kotas A., Ślusarczyk Z., Pięta M., Szostak A., 2012, Analysis of the relationship between water quality indicators in Goczałkowice Lake in the aspect of phytoplankton blooms, Environmental Protection 1(34), 21-27. [in Polish]
9. Forsberg C. 1992, Eutrophisation of the Baltic Sea, Baltic Sea Environment, Book 3. [in Polish]

10. Jeannot R., 1994, Intern. J. Environ. Anal. Chem. 57, p. 231.

11. Kajak Z., 2001, Hydrobiology - Limnology. Inland water ecosystems, PWN Scientific Publishing House, Warszawa. [in Polish]

12. Kasprzak P., Padisak J., Koschel R., Krienitz L., Gervais F., 2008, Chlorophyll a concentration across a trophic gradient of lakes: An estimator of phytoplankton biomass?, Limnologica - Ecology and Management of Inland Waters, 38(3-4), 327-338.

13. Kot-Wasiak A., Morawska M., Namieśnik J., 2001, Degradation of organic compounds in the environment, Chemical Ecol. Engin. 8, p. 179. [in Polish]

14. Kowalewski Z., 2012, Ph.D. thesis - Verifying the possibility of using an integral criterion to assess the trophic status of flowing waters. AGH University of Science and Technology, Cracow [in Polish]

15. Namikoshi M., Murakami T., Watenabe M.,F., Oda T., Yamada J., Tsujimura S., Nagai H., Oishi S., 2003, Simultaneous production of homanatoxin-a, Anatolina, and new non-toxic 4 -hydroxyhomoanatoxin-a by the cyanobacterium Raphidiopsis mediterranea, Skuja, Toxicon 42(5), 533-538,

16. Neverowa-Dziopak E., 2010, Fundamentals of management of anthropogenic eutrophication process, Monograph, AGH Publishing House, Cracow [in Polish]

17. Rynkiewicz A., 2007, Problems of water eutrophication in Poland and their natural limitation, National Water Management Board, Poznań, 1-13. [in Polish]

18. Sapek B., 2014, Accumulation and release of phosphorus in soils-sources, processes, causes, WaterEnvironment-Rural Areas (I-III). T. 14. Z. 1(45), 78-100. [in Polish]

19. Szczykowska J., Siemieniuk A., Wiater J., 2015, Operating difficulties of small water reservoir located in Wasilków, J. Ecol. Eng., 16(1), 122-126.

20. Szczykowska J., Siemieniuk A., Wiater J., 2015, Agricultural pollution and water quality in small retention reservoir in Korycin, J. Ecol. Eng. 16(1), 141-146.

21. Szczykowska J., Siemieniuk A., Wiater J.,2015, Diversity of the TSI indicators of the middle-forest small retention reservoir, J. Ecol. Eng, 16(5), 54-61

22. Zdanowski B., 1983, Ecological characteristics of lakes in north eastern Poland versus their trophic gradient. Part V. Chlorophyll content and visibility of Secchi's disc in 46 lakes, Ekol. Pol., 31(2), 333-352.

23. Żak J., Grześkowiak A., Brodzińska B., Sziwa R., Nowak D, Nowak B. 2007, Assessment of the protection of the Wojnowskie and Rudno lakes along with the possibility of adapting the Rudno lake for retention purposes, Work done at the request of the Lubuskie Region, Institute of Meteorology and Water Management, Poznan Branch, Poznan. [in Polish] 